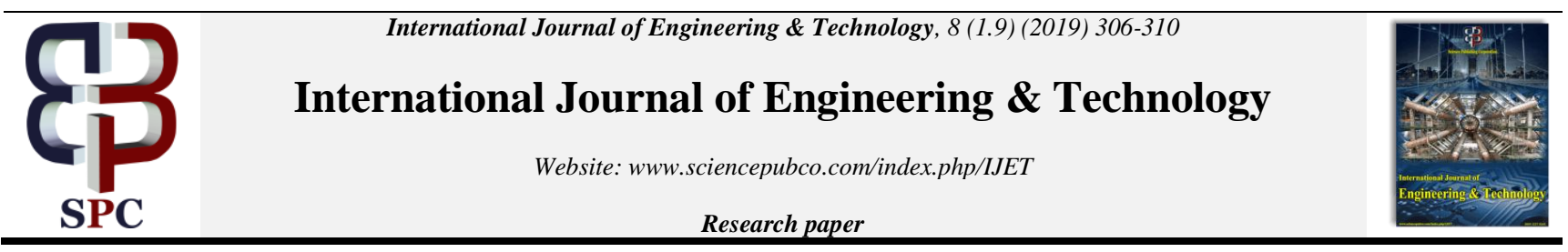

\title{
Formulations of Organic Matter for Biodegridable Planting Bag
}

\author{
Mochammad Chanan ${ }^{1}$, Aniek Iriany ${ }^{2 *}$ and Atiek Iriany ${ }^{3}$ \\ ${ }^{I}$ Department of Forestry, Faculty of Agriculture and Animal Husbandry, University of University of Muhammadiyah Malang, Indonesia \\ University of Muhammadiyah Malang, Malang 65144, Indonesia \\ ${ }^{2}$ Department of Agriculture, Faculty of Agriculture and Animal Husbandry, University of University of Muhammadiyah Malang, Indone- \\ sia University of Muhammadiyah Malang, Malang 65144, Indonesia \\ ${ }^{3}$ Department of Statistics, Faculty of Mathematics and Natural Sciences Brawijaya University, Malang 65145, Indonesia \\ *Corresponding author E-mail: atiekiriany@yahoo.com
}

\begin{abstract}
This research was aimed to generate an efficient and effective material formulation of planting bag using organic waste which could be applied to support the plant nursery technology. This research was conducted using completely randomized design with three times replication. The observable variables were: the chemical content of material including organic $\mathrm{C}, \mathrm{C} / \mathrm{N}, \mathrm{SOM}$, and $\mathrm{N}$ total. The variables of material quality were yield, tensile strength, and Valensky test. The result of this research indicated that the material composition of $25 \%$ water hyacinth: $50 \%$ straw: $25 \%$ banana sheath produced higher $\mathrm{N}$ total, organic $\mathrm{C}$ and organic matters. Then, the material composition of $50 \%$ water hyacinth: $25 \%$ straw: $25 \%$ banana sheath generate material quality with higher tensile strength $(33 \mathrm{~N} / \mathrm{cm} 2)$. While the material composition consisting of $25 \%$ water hyacinth: $25 \%$ straw: $50 \%$ banana sheath produced higher yield value (80\%). Due to the material proportion of water hyacinth, straw, and banana sheath, it affected the decrease and increase of light intensity whether in all season. It means biodegradable planting bag potentially substitute polybag or in organic planting bag with satisfied physical and mechanical properties.
\end{abstract}

Keywords: Planting Bag, Organic Matter, Composition

\section{Introduction}

Tree planting program is highly determined by the initial step of planting, high-quality seeds and its exact amount have been provided to meet the seeds quality standard. High-quality seeds will determine the good growth rate in the field. All of this time, the farmers still use polybag as growing media in seeds production (Sivan, 2011). There are some disadvantages using polybag as growing media such as plastic degradation problem which is undegradable and makes the damaged land (Kyrikou \& Briassoulis, 2007; O\&apos; Brine \& Thompson, 2010); the expensive price of polybag materials causes many problems since the farmers must spend more money to overcome the higher production cost. The anthropogenic effect of using polybag is the increase of plastic accumulation and fragmentation particularly in the field of agriculture and forestry which can be seen from the escalation of PE, PET, HDPE, LDPE plastic use in the cultivation process (Barnes, Galgani, Thompson, \& Barlaz, 2009; Pinto, Costa, Gulyurtlu, \& Cabrita, 1999). While from the technical aspect, using plastic as growing media is less practical since the seeds often have stagnation problem when it is planted in the field; the plastic must be removed first.

Potential problems with conventional polybag seedling production include root spiraling, roots regressing into the nursery beds and lost upon harvest, and poor media drainage. These problems can result in seedlings with deformed, damaged or poorly developed root systems that can decrease out planting survival and growth. The polybag system lacks the root-control ribs and bottom air pruning designs that are typically present in rigid container systems. Therefore, seedlings may develop spiraled root systems that can negatively affect growth and performance of the trees a few years after out planting (Aldrete, Mexal, Phillips, \& Vallotton, 2002). To overcome those problems, there is a need to review an alternative way of utilizing organic matters such as water hyacinth, straw and banana sheath which can be easily found nearby; those materials can be used to produce grow bags (Friger dan Matsunaka 1997; Hronich et al. 2008; Villamagna and Murphy 2010; Aboul-Enein et al. 2011).

There are sufficient amount of organic matters in the form of organic waste and plants which can be found nearby. However, it has not been maximally utilized. Those matters can be used as the materials to produce planting bag for seeds production. It is a simple technology which gives some benefits such as cheap price, applicable and effective usage, simple production technology, and biodegradable (Nauli, 2007; Jiang, Yan, and Li 2010). This research was conducted to generate an efficient and effective material formulation of planting bag as well as produce a package of seedling technology by using organic and biodegradable planting media. 


\section{Materials and Methods}

This research was performed inside a laboratory and glasshouse in experimental garden of the University of Muhammadiyah Malang. It was conducted from May - July 2015. The equipment used in this research were: digital scale, scissor, graduated cylinder, blender, Styrofoam, sieve, Brazillian test (used to measure penetration resistance and mulch tensile strength) and growing media mold. Then, using the materials can be made the sheets of the organic bag: water hyacinth, straw, banana sheath, $\mathrm{NaOH}$ and Urea.

Completely randomized design (CRD) was used in this research. The treatments of planting bag material composition consisted of 6 treatments with 3 replications, they were M1 $=50 \%$ water hyacinth: $25 \%$ straw: $25 \%$ banana sheath; $\mathrm{M} 2=25 \%$ water hyacinth $: 50 \%$ straw : $25 \%$ banana sheath; $\mathrm{M} 3=25 \%$ water hyacinth: $25 \%$ straw: $50 \%$ banana sheath; $\mathrm{M} 4=100 \%$ water hyacinth; $\mathrm{M} 5=100 \%$ straw; M6 $=100 \%$ banana sheath. The variables which were observed its chemical content were organic C, C/N, SOM, and N total. The measured variables were materials strength and resistance which were measured by performing a normal stress test specifically Brazilliant test (N/cm2), water absorbency (\%), Vilensky test, and yield.

\section{Results and Discussions}

The results of chemical analysis of planting bag materials on various treatments are shown in Table 1 while the measurement results of tensile strength and yield material values are shown in Table 2. Correlations between material proportion (\%) and tensile strength (N) and correlations between material proportion (\%) and yield (\%) are presented in Figure 1 and 2.

Table 1: The Chemical Content of Organic Material for Planting Bag

\begin{tabular}{lcrrr}
\multicolumn{5}{c}{ Table 1: The Chemical Content of Organic Material for Planting Bag } \\
\hline \multicolumn{1}{c}{ Treatment } & Organic C & N-total & C/N & Organic Matter \\
\hline $\mathrm{M}_{1}(50: 25: 25)$ & $27.067 \mathrm{~b}$ & $8.743 \mathrm{~d}$ & $3.333 \mathrm{a}$ & $42.487 \mathrm{c}$ \\
$\mathrm{M}_{2}(25: 50: 25)$ & $32.433 \mathrm{a}$ & $13.360 \mathrm{a}$ & $4.000 \mathrm{a}$ & $51.653 \mathrm{a}$ \\
$\mathrm{M}_{3}(25: 25: 50)$ & $31.467 \mathrm{a}$ & $10.783 \mathrm{bcd}$ & $4.667 \mathrm{a}$ & $43.467 \mathrm{bc}$ \\
$\mathrm{M}_{4}(100: 0: 0)$ & $26.000 \mathrm{~b}$ & $9.327 \mathrm{~cd}$ & $4.667 \mathrm{a}$ & $43.837 \mathrm{bc}$ \\
$\mathrm{M}_{5}(0: 100: 0)$ & $32.533 \mathrm{a}$ & $11.340 \mathrm{abc}$ & $5.333 \mathrm{a}$ & $48.273 \mathrm{ab}$ \\
$\mathrm{M}_{6}(0: 0: 100)$ & $34.000 \mathrm{a}$ & $12.217 \mathrm{ab}$ & $6.333 \mathrm{a}$ & $44.523 \mathrm{bc}$ \\
\hline
\end{tabular}

Information: Numbers followed by the same letter show insignificant differences based on HSD test 5\%

Table 1 shows that $100 \%$ straw proportion had higher organic C content, 34\%, which was not different from 100\% straw composition (M5), M2 (25:50:25) and M3 (25:25:50). M2 composition (25:50:25) produced higher total N value (13.36\%). However, it was not different from M5 composition (0:100:0) and M6 (0:0:100). The $\mathrm{C} / \mathrm{N}$ ratio content shows that all proportion in all compositions were not significantly different in term of organic matter content proportion, on M2 composition (25:50:25) for example, it was of higher Organic Matter as much as $51.653 \%$ but not significantly different from M5 composition (0:100:0). Generally, fresh water hyacinth is of $95.5 \%$ water, $0.04 \% \mathrm{~N}, 1.0 \%$ ash, $0.06 \% \mathrm{P} 2 \mathrm{O} 5,0.20 \% \mathrm{~K} 2 \mathrm{O}$ and $3.5 \% \mathrm{OMs}$ while in a dry version, it is of $75.8 \% \mathrm{OM}, 1.5 \% \mathrm{~N}$, and $24.2 \%$ ash that consists of $28.7 \% \mathrm{~K} 2 \mathrm{O}, 1.8 \% \mathrm{Na} 2 \mathrm{O}, 12.8 \% \mathrm{CaO}, 21.0 \% \mathrm{Cl}$, and $7.0 \% \mathrm{P} 2 \mathrm{O} 5$ (Jafari, 2010). On the other hands, straw is of nutrient contents such as $40.87 \%$ OMs, $1.01 \%$ N, $0.15 \%$ P, and $1.75 \% \mathrm{~K}$ (Fadriansyah, 2015). Water hyacinth can accelerate the nutrient recycle potency in wetlands where the total ecosystem services can be temporarily managed (Balasubramanian et al. 2012).

Table 2: Tensile Strength (N) and Yield (\%) of Planting Bag Material

\begin{tabular}{lll}
\hline Treatment & Tensile Strength $\left(\mathbf{N} / \mathbf{c m}^{2}\right)$ & Yield $(\%)$ \\
\hline $\mathbf{M}_{1}(50: 25: 25)$ & $33.303 \mathrm{a}$ & $73.663 \mathrm{~b}$ \\
$\mathrm{M}_{2}(25: 50: 25)$ & $30.513 \mathrm{bc}$ & $76.543 \mathrm{ab}$ \\
$\mathrm{M}_{3}(25: 25: 50)$ & $32.000 \mathrm{ab}$ & $80.190 \mathrm{a}$ \\
$\mathrm{M}_{4}(100: 0: 0)$ & $28.650 \mathrm{c}$ & $66.673 \mathrm{c}$ \\
$\mathrm{M}_{5}(0: 100: 0)$ & $25.293 \mathrm{~d}$ & $63.733 \mathrm{c}$ \\
$\mathrm{M}_{6}(0: 0: 100)$ & $28.680 \mathrm{c}$ & $62.493 \mathrm{c}$ \\
\hline
\end{tabular}

Information: Numbers followed by the same letter show insignificant differences based on HSD Test 5\%

Table 2 shows that the proportion of M1 composition (50:25:25) was of higher tensile strength value which was $33.303 \mathrm{~N} / \mathrm{cm} 2$. The value was not significantly different from the value of M3 composition (25:25:50) which was $32 \mathrm{~N} / \mathrm{cm} 2$, but it was different from the other compositions; M2 (24:50:25), M4 (100:0:0), M5 (0:100:0) and M6 (0:0:100) compositions. The compositions of 25\% water hyacinth, $25 \%$ straw and 50\% banana sheath (25:25:50) produced higher yield value which was $80.19 \%$ but it was still not significantly different from yield value in the proportion of 35\% water hyacinth, $50 \%$ straw, and $25 \%$ banana sheath composition which was $76.54 \%$. Figure 1 shows that the correlation between straw proportion with water hyacinth proportion and tensile strength got relatively high R2s which were $88.2 \%$ and $83.8 \%$ respectively. This suggests that the proportions of such materials were of low variability tensile strength. Different from the correlation between banana stem proportion and tensile strength, it was obtained the lower R2 value (69.2\%), this shows that the variability tensile strength on banana sheath proportion was bigger. From that analysis, we could infer that the use of water hyacinth and straw as planting bag compositions was suitable since both resulted in the low variability tensile strength. The maximum tensile strength obtained from straw composition was $25 \%$ and for water hyacinth one, it was $50 \%$. Whereas the use of various levels of banana sheath proportion did not yet result in maximum tensile strength because of the high variability tensile strength. However, it can be seen that the highest tensile strength was obtained from 50\% banana sheath composition, it is just the same as the previous research that the $50 \%$ banana sheath composition was of higher tensile strength rather than $40 \%$ and $60 \%$ ones when combined with epoxy resins (Ramesh, Ananda, Aswin, Eashwar, \& Deepa, 2014). Next, the product of this straw material needs to be tested to ensure its resistance and strength when it is used (Mediastika, 2009). Therefore, other combinations of water hyacinth proportion and other suitable materials are needed. Besides, it needs to consider adding other materials to maximize mulch tensile strength. 

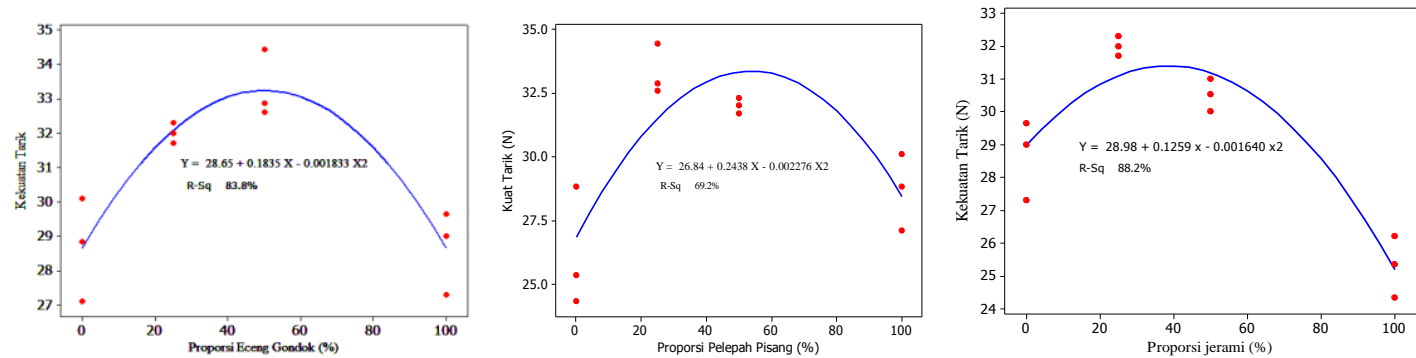

Fig 1: Correlation between Material Proportion (\%) and Tensile Strength (N/cm2)

Figure 2 shows that the correlation between straw and banana sheath proportion and yield got relatively high R2 which were $91.6 \%$ and $94.1 \%$ respectively. This shows that such proportion was of low variability yield value. From that analysis, it suggests that the use of banana stem and straw as planting bag materials was suitable since they produced low variability yield value. The maximum yield value obtained on the banana sheath and straw proportions were 50\% and 50\% respectively while the use of various levels of water hyacinth proportion did not yet result in maximum yield value because it was still of high variability. Thus, other combinations of water hyacinth and other proportion that are more suitable are needed. Besides, it needs to consider adding other materials to maximize the material yield values.
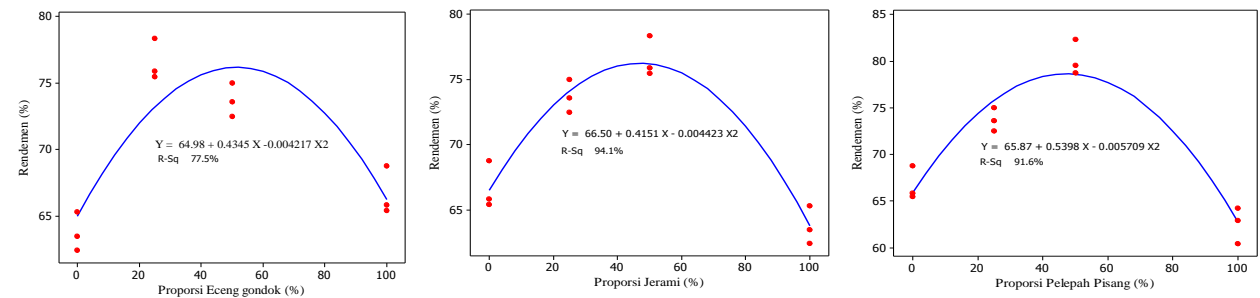

Fig 2: Correlation between material Proportion (\%) and Yield (\%)

Reviewed from the water hyacinth proportion used in planting bag materials, when the material was wet (Figure 3), we can see that quadratic curve was formed with the peak point at 50\% proportion. This suggests that the increase and the decrease of water hyacinth proportion effect on the decrease of light intensity. When the material was dry, linear correlation pattern was formed, which suggests that the increase of water hyacinth proportion effects on the increase of light intensity.
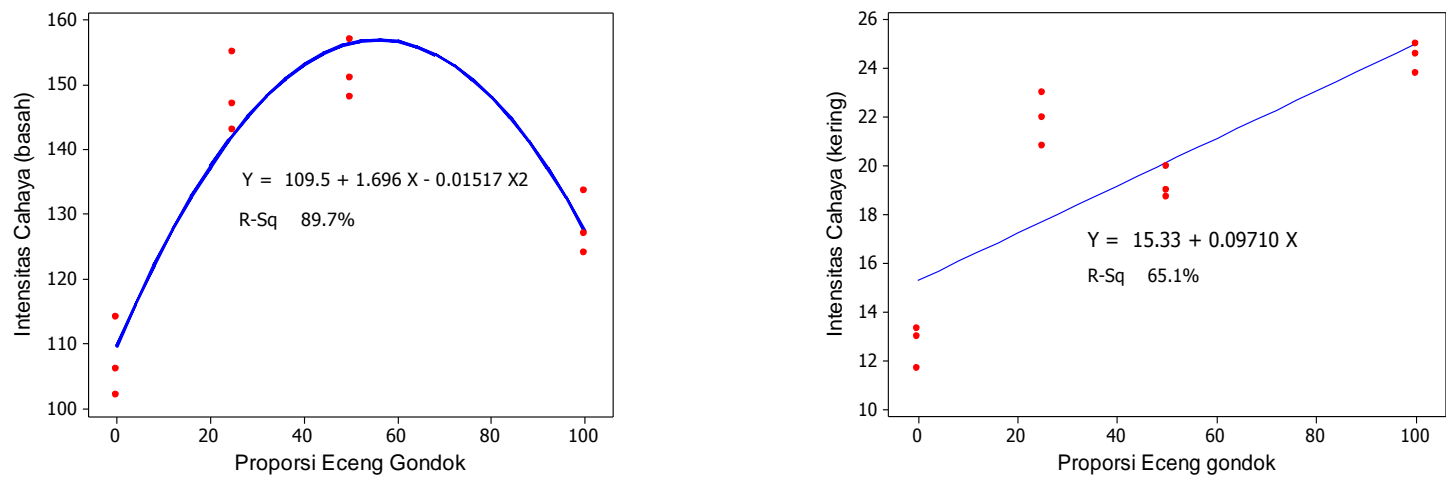

Fig 3: Correlation between Light Intensity and Proportion of Water Hyacinth on Planting Bag in Wet and Dry Condition
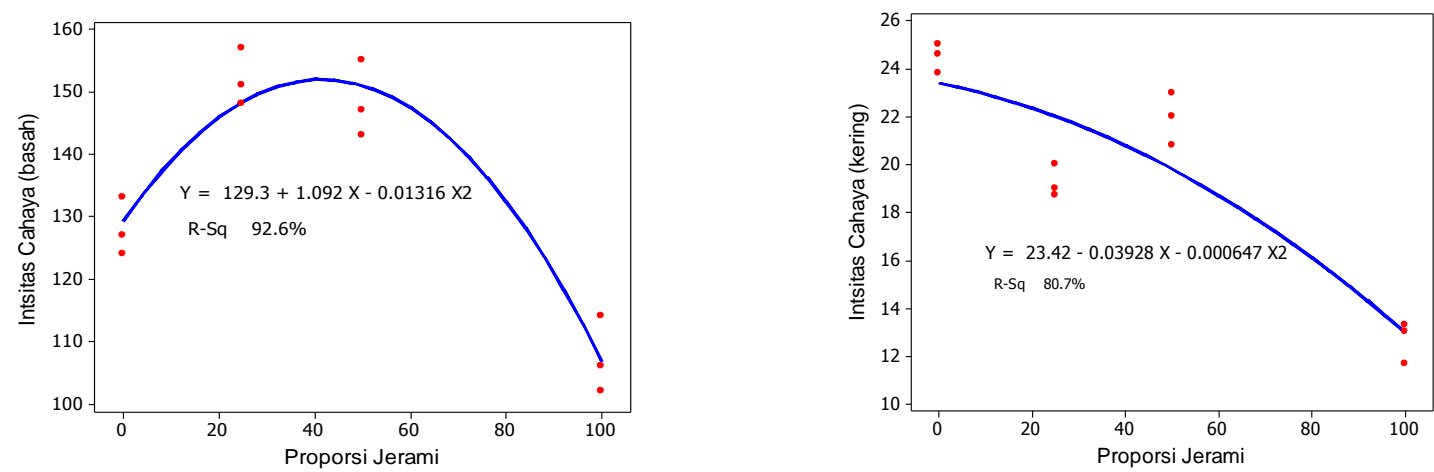

Fig 4: Correlation between Light Intensity and Proportion of Straw Content on Planting Bag in Wet and Dry Condition 
Reviewed from straw proportion used in planting bag material, when the material was wet (Figure 4), the quadratic curve was formed with the peak point at $50 \%$ proportion. When the material was dry, the peak point was at $0 \%$ straw proportion. This suggests that the increase and the decrease of straw proportion affect the increase of light intensity when the material is wet. In dry condition, the increase of straw proportion will decrease the light intensity.
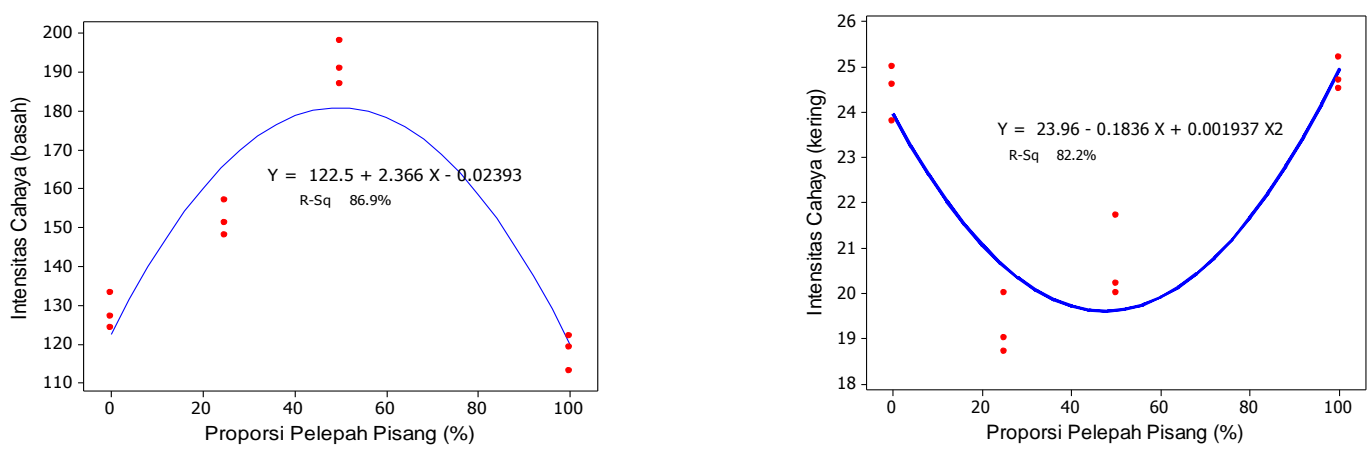

Fig 5: Correlation between Light Intensity and banana sheath Proportion on Planting Bag in Wet and Dry Condition

Figure 5 shows the proportion of banana sheath contents used in planting bag material. When the material was wet, we can see that a decreased quadratic curve was formed. It means that when it was wet, the increase of banana sheath proportion would decrease the light intensity, otherwise, the curve will have an upward trend. This suggests that there was a minimum point of light intensity at 50\% proportion. The increase of banana sheath proportion will increase the light intensity.

The composition of $50 \%$ water hyacinth: $25 \%$ straw: $25 \%$ banana sheath resulted in material quality with higher tensile strength value (33 N/cm3). The composition of 25\% water hyacinth: $25 \%$ straw: $50 \%$ banana sheath resulted in higher yield value $(80 \%)$. Reviewed from water hyacinth proportions used in planting bag material, when the material is wet, the increase and the decrease of water hyacinth proportion would effect on the decrease of light intensity. When the material was dry, the increase of water hyacinth proportion would effect on the decrease of light intensity. Analyzed from the straw proportion used in planting bag material, when the material was wet, the increase and the decrease of straw proportion would effect on the decrease of light intensity. When dry, the increase of straw proportion would result in the decrease of light intensity. When the proportion of banana sheath content used in planting bag was wet, the increase of banana sheath proportion would effect on the decrease of light intensity while when it was dry, the increase of banana stem proportion resulted in the increase of light intensity.

\section{Conclusion}

The composition of 25\% Hyacinth: $50 \%$ Straw: $25 \%$ banana sheath produce content of total N, C-organic and organic materials higher material composition of 50\% Hyacinth: $25 \%$ Straw: $25 \%$ banana sheath producing quality materials with strong value higher tensile $(33 \mathrm{~N} / \mathrm{cm})$. The composition of the $25 \%$ Hyacinth: $25 \%$ Straw: $50 \%$ banana sheath produce a higher yield value ( $80 \%)$. Changes in the proportion of material hyacinth, straw and banana sheath affect the increase or decrease in the intensity of light.

\section{References}

[1] Aboul-Enein, Ahmed M. et al. (2011). "Eichhornia Crassipes (Mart) Solms: From Water Parasite to Potential Medicinal Remedy." Plant Signaling \& Behavior 6(6):834-36.

[2] Aldrete, A., Mexal, J. G., Phillips, R., \& Vallotton, A. D. (2002). Copper coated polybags improve seedling morphology for two nursery-grown Mexican pine species. Forest Ecology and Management, 163(1-3), 197-204. http://doi.org/10.1016/S0378-1127(01)00579-5

[3] Barnes, D. K. a, Galgani, F., Thompson, R. C., \& Barlaz, M. (2009). Accumulation and fragmentation of plastic debris in global environments. Philosophical Transactions of the Royal Society of London. Series B, Biological Sciences, 364(1526), 1985-1998. http://doi.org/10.1098/rstb.2008.0205

[4] Fadriansyah, A. (2015). Pengaruh takaran Mulsa Jerami Padi Terhadap Pertumbuhan dan Hasil Tanaman Kedelai (Glycine max L). Statewide Agricultural Land Use Baseline 2015, 1, 1-14. http://doi.org/10.1017/CBO9781107415324.004

[5] Friger, J. D. dan Matsunaka, S., (1997). Penanggulangan Gulma Secara Terpadu. Bina Aksara. Jakarta.

[6] Hronich, J. E., Martin, L., Plawsky, J., \& Bungay, H. R. (2008). Potential of Eichhornia crassipes for biomass refining. Journal of Industrial Microbiology \& Biotechnology, 35(5), 393-402. http://doi.org/10.1007/s10295-008-0333-x

[7] Jafari, N. (2010). Ecological and socio-economic utilization of water hyacinth (Eichhornia crassipes Mart Solms). Journal of Applied Sciences and Enviromental Management, 90(June), 43-49. http://doi.org/10.4314/jasem.v14i2.57834

[8] Jiang, Wei-jun, You-ping Yan, and Ping. Li. (2010). "Progress in Resources Utilization of Eichhornia Crassipes." Shuiziyuan Baohu, 26(6):79-83.

[9] Kyrikou, I., \& Briassoulis, D. (2007). Biodegradation of Agricultural Plastic Films: A Critical Review. Journal of Polymers and the Environment, 15(2), 125-150. http://doi.org/10.1007/s10924-007-0053-8

[10] Mediastika, C. E. (2009). Jerami Sebagai Bahan Baku Panel Akustik Pelapis Dinding. Jurnal Teknik Arsitektur. doi:10.9744/dimensi.36.1.pp. 2027

[11] Nauli, A. (2007). Pengolahan Eceng Gondok Sebagai Bahan Baku Kertas Seni. Ekspose Hasil-Hasil Penelitian, (September), 111-118.

[12] O’Brine, T., \& Thompson, R. C. (2010). Degradation of plastic carrier bags in the marine environment. Marine Pollution Bulletin, 60(12), 22792283. http://doi.org/http://dx.doi.org/10.1016/j.marpolbul.2010.08.005

[13] Oppong, F. K., Ofori-Frimpong, K., \& Fiakpornu, R. (2007). Effect of polybag size and foliar application of urea on cocoa seedling growth. Ghana Journal of Agricultural Science, 40(2), 207-213. Retrieved from http://www.ajol.info/index.php/gjas/article/view/2172

[14] Pinto, F., Costa, P., Gulyurtlu, I., \& Cabrita, I. (1999). Pyrolysis of plastic wastes. 1. Effect of plastic waste composition on product yield. Journal of Analytical and Applied Pyrolysis, 51(1), 39-55.

[15] Ramesh, M., Ananda, T. S., Aswin, U. S., Eashwar, H., \& Deepa, C. (2014). Processing and Mechanical Property Evaluation of Banana Fiber Reinforced Polymer Composites. Procedia Engineering, 97, 563-572. http://doi.org/10.1016/j.proeng.2014.12.284 
[16] Palm, C. A., Giller, K. E., Mafongoya, P. L., \& Swift, M. J. (2001). Management of organic matter in the tropics: translating theory into practice. Nutrient Cycling in Agroecosystems, 61(1), 63-75. http://doi.org/10.1023/A:1013318210809

[17] Pinto, F., Costa, P., Gulyurtlu, I., \& Cabrita, I. (1999). Pyrolysis of plastic wastes. 1. Effect of plastic waste composition on product yield. Journal of Analytical and Applied Pyrolysis, 51(1), 39-55.

[18] Sain, M., \& Panthapulakkal, S. (2006). Bioprocess preparation of wheat straw fibers and their characterization. Industrial Crops and Products, 23(1), $1-8$.

[19] Sivan, A. (2011). New perspectives in plastic biodegradation. Current Opinion in Biotechnology

[20] Villamagna, A. M., and B. R. Murphy. 2010. "Ecological and Socio-Economic Impacts of Invasive Water Hyacinth (Eichhornia Crassipes): A Review." Freshwater Biology, 55(2):282-98. 